\title{
Pengaruh Kinerja Keuangan Terhadap Harga Saham Bank Umum Konvensional di Bursa Efek Indonesia Pada Tahun 2013-2016
}

\author{
Leni Yuliyanti ${ }^{1}$, Badria Muntashofi ${ }^{2}$, Nuraeni Dewi Asih $^{3}$ \\ Program Studi Pendidikan Akuntansi, FPEB, Universitas Pendidikan Indonesia, Bandung, Indonesia ${ }^{1}$ \\ Program Studi Pendidikan Akuntansi, FPEB, Universitas Pendidikan Indonesia, Bandung, Indonesia ${ }^{2}$ \\ Program Studi Pendidikan Akuntansi, FPEB, Universitas Pendidikan Indonesia, Bandung, Indonesia ${ }^{3}$
}

\begin{abstract}
.
This study aims to determine the effect of financial performance which is divided into four components of financial ratios, namely capital, credit risk, liquidity risk, and profitability to the stock prices of conventional commercial banks on the Indonesia Stock Exchange in 2013-2016. The capital in this study is measured using the Capital Adequacy Ratio (CAR), credit risk is measured using Non Performing Loans (NPL), liquidity risk is measured using Loan to Deposit Ratio (LDR), profitability is measured using Return On Assets (ROA), while the stock price in this study is measured by the annual closing stock price. The research method used in this research is descriptive and verification method. Purposive sampling is used to determine research samples with a total sample of 10 banks during 4 years of research. The statistical analysis used in this study is a multiple panel linear data analysis. Based on the results of the significance test regression coefficient (Test F) shows that the regression model can be used to draw conclusions. While the results of the t test show that capital has a positive effect on stock prices, credit risk has a negative effect on stock prices, profitability has a positive effect on stock prices, liquidity risk has a positive and not significant effect on stock prices.
\end{abstract}

Keywords. Capital; credit risk; liquidity risk; stock price.

\begin{abstract}
Abstrak
Penelitian ini bertujuan untuk mengetahui pengaruh kinerja keuangan yang terbagi kedalam empat komponen rasio keuangan yaitu permodalan, risiko kredit, risiko likuiditas, dan rentabilitas terhadap harga saham bank umum konvensional di Bursa Efek Indonesia tahun 2013-2016. Permodalan dalam penelitian ini diukur dengan menggunakan Capital Adequacy Ratio (CAR), risiko kredit diukur dengan menggunakan Non Performing Loan (NPL), risiko likuiditas diukur dengan menggunakan Loan to Deposit Ratio (LDR), rentabilitas diukur dengan menggunakan Return On Asset (ROA), sedangkan harga saham dalam penelitian ini diukur melalui harga saham penutupan tahunan. Metode penelitian yang digunakan dalam penelitian ini adalah metode deskriptif dan verifikatif. Purposive sampling digunakan untuk menentukan sampel penelitian dengan jumlah sampel sebanyak 10 bank selama 4 tahun penelitian. Analisis statistik yang digunakan dalam penelitian ini adalah analisis regresi linier multipel data panel. Berdasarkan hasil pengujian keberartian koefisien regresi (Uji F) menunjukkan bahwa model regresi dapat digunakan untuk mengambil suatu kesimpulan. Sedangkan hasil uji t menunjukkan bahwa permodalan berpengaruh positif terhadap harga saham, risiko kredit berpengaruh negatif terhadap harga saham, rentabilitas berpengaruh positif terhadap harga saham, risiko likuiditas berpengaruh positif tidak signifikan terhadap harga saham.
\end{abstract}

Kata Kunci : Permodalan; risiko kredit; risiko likuiditas, harga saham;

Corresponding author. Email. yuliyanti_leni@upi.edu¹, badria_mshofi@gmail.com²

How to cite this article. Yuliyanti, L., Muntashofi, B., \& Asih, N. D. (2017). Pengaruh Kinerja Keuangan Terhadap Harga Saham Bank Umum Konvensional di Bursa Efek Indonesia Pada Tahun 2013-2016 Sumber: Data Diolah. Jurnal Pendidikan Akuntansi Dan Keuangan, 5(1), 39-54. Retrieved from http://ejournal.upi.edu/index.php/JPAK/article/view/15408

History of article. Received: Agustus 2016, Revision: November 2016, Published: Januari 2017

\section{Pendahuluan}

Pasar Modal merupakan tempat dimana terjadinya permintaan dan penawaran atas surat berharga. Para penanam dana dan perusahaan bertemu di pasar modal dalam rangka tawar menawar surat berharga. Menurut UU No. 8 
tahun 1995 tentang Pasar Modal, "Pasar modal adalah kegiatan yang bersangkutan dengan penawaran umum dan perdagangan efek, perusahaan public yang berkaitan dengan efek yang diterbitkannya, serta lembaga dan profesi yang berkaitan dengan efek."

Bagi perusahaan yang telah go public dengan menerbitkan saham dan menjualnya kepada investor melalui Bursa Efek Indonesia (BEI), pasar modal merupakan sumber dana untuk meningkatkan permodalan. Sedangkan bagi investor, pasar modal merupakan tempat untuk menanamkan dana pada suatu perusahaan atau emiten dengan membeli saham perusahaan yang dikehendaki yang kemudian hal ini disebut dengan investasi.

Pasar modal merupakan pasar yang memperjualbelikan instrumen keuangan jangka panjang. Sesuai dengan yang dikemukakan oleh Darmadji dan Fakhruddin (2011:1) "Pasar modal merupakan pasar untuk berbagai instrument keuangan jangka panjang yang bisa diperjualbelikan, baik dalam bentuk utang ataupun modal sendiri." Instrumen keuangan jangka panjang yang diperjualbelikan seperti surat berharga, saham, obligasi, waran, dan instrumen keuangan jangka panjang lainnya. Saham merupakan salah satu instrumen keuangan jangka panjang yang diperjualbelikan dalam pasar modal.

Saham dapat dikatakan sebagai tanda kepemilikan seseorang atau badan dalam suatu perusahaan. Saham dikeluarkan oleh emiten yang telah go pulic dan sudah terdaftar di Bursa Efek Indonesia (BEI). Penerbitan saham oleh perusahaan merupakan upaya dalam mendapatkan tambahan dana. Husnan dan Pudjiastuti (2006:7) mengemukakan bahwa "Bagi perusahaan yang mengeluarkan saham di pasar modal, harga saham yang diperjualbelikan di bursa merupakan indikator nilai perusahaan."

Nilai perusahaan merupakan kondisi yang telah dicapai oleh perusahaan yang sanggup dibayar oleh investor. Apabila kinerja perusahaan baik maka nilai perusahaan pun akan baik, sebaliknya apablia kinerja perusahaan buruk maka akan berpengaruh buruk pula pada nilai perusahaan. Semakin baik kinerja perusahaan maka semakin banyak pula investor yang tertarik untuk menanamkan dananya pada perusahaan. Nilai perusahaan akan tercermin dalam harga saham emiten. Harga saham merupakan nilai yang tergantung pada lembar saham yang diterbitkan emiten.

Harga saham terbentuk oleh hukum ekonomi atas permintaan dan penawaran yang terjadi di pasar modal atau bursa efek yang dilatarbelakangi oleh harapan menadapatkan keuntungan. Harga saham dapat menunjukkan bagaimana nilai perusahaan suatu emiten. Nilai perusahaan ditunjukkan oleh bagaimana kinerja emiten. Harga saham akan berfluktuasi sesuai dengan permintaan dan penawaran atas saham tersebut. Pada tahun 2013-2016 Indeks Harga Saham Sub Sektor Perbankan menunjukkan fluktuasi yang terus bergerak. Hal ini dapat dilihat dalam tabel 1 yang menunjukkan indeks harga saham sub sektor bank yang berfluktuatif, sebagai berikut :

Tabel 1. Indeks Harga Saham Sub Sektor Bank Tahun 2013-2016

\begin{tabular}{cccc}
\hline Tahun & $\begin{array}{c}\text { Nilai Dasar } \\
\text { (Bill.) }\end{array}$ & $\begin{array}{c}\text { Nilai Pasar } \\
\text { (Bill.) }\end{array}$ & Indeks \\
\hline 2013 & 894.282 & 894.282 & 100 \\
2014 & 894.282 & 1.222 .294 & 136,6 \\
2015 & 894.282 & 1.132 .972 & 126,7 \\
2016 & 894.282 & 1.339 .854 & 149,8 \\
\hline \multicolumn{4}{l}{ Sumber: Data Diolah }
\end{tabular}

Berdasarkan data diatas indeks harga saham sub sektor perbankan mengalami fluktuasi ditunjukkan dengan naik dan turunnya harga saham. Dengan melihat fenomena di atas seharusnya harga saham sub sektor perbankan terus bergerak naik agar investor tertarik untuk menanamkan dananya. Tetapi pada kenyataannya masih terdapat beberapa harga saham perusahaan perbankan yang bergerak turun. Hal ini bertolak belakang dengan idealnya pergerakan harga saham yang seharusnya terus bergerak naik. Berikut merupakan harga saham perusahaan perbankan yang cenderung mengalami penurunan pada tahun 2013-2016, disajikan dalam gambar 2 : 


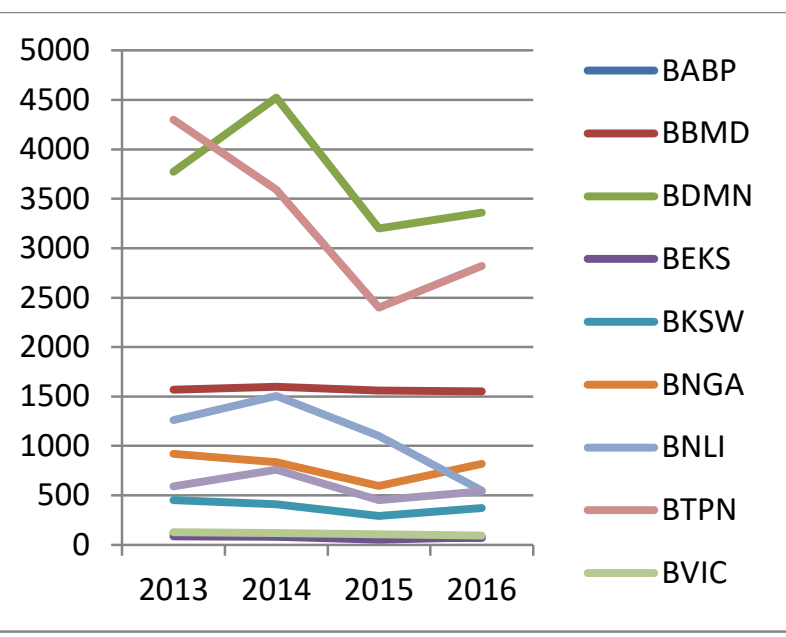

Gambar 2. Harga Saham Bank Umum Konvensional yang Mengalami Penurunan Tahun 2013-2016

Dari data di atas dapat dilihat bahwa terdapat harga saham 10 perusahaan perbankan yang cenderung mengalami penurunan dari tahun 2013-2016. Perusahaan perbankan yang cenderung mengalami penurunan tersebut di antaranya adalah Bank MNC Internasional Tbk mengalami penurunan sebesar 48,87\%, Bank Mestika Dharma Tbk mengalami penurunan sebesar 4,45\%, Bank Danamon Indonesia Tbk mengalami penurunan sebesar 1,72\%, Bank Pembangunan Daerah Banten Tbk mengalami penurunan sebesar 32,14\%, Bank QNB Indonesia Tbk mengalami penurunan sebesar 28,88\%, Bank CIMB Niaga Tbk mengalami penurunan sebesar $8,15 \%$, Bank Permata Tbk mengalami penurunan sebesar 55,95\%, Bank Tabungan Pensiunan Nasional Tbk mengalami penurunan sebesar 38,60\%, Bank Victoria Internasional Tbk mengalami penurunan sebesar $14,4 \%$, Bank National Nobu Tbk mengalami penurunan sebesar $8,47 \%$.

Apabila pergerakan harga saham sub sektor bank yang menurun ini terjadi secara terus menerus akan berdampak pada kepercayaan investor yang terus menurun pula. Dengan menurunnya harga saham sub sektor bank, investor akan menilai bahwa kinerja keuangan pada perusahaan perbankan mengalami kemunduran. Kinerja keuangan perusahaan perbankan yang buruk akan menyebabkan berubahnya keputusan investasi yang diambil oleh investor. Terlebih investor tidak akan tertarik untuk menanamkan dananya dan mengurungkan niatnya dalam berinvestasi. Semakin buruknya kinerja keuangan perusahaan perbankan maka semakin tidak menarik perhatian para investor. Dengan menurunnya ketertarikan investor untuk berinvestasi pada perusahaan perbankan, maka harga saham sub sektor perbankan pun akan semakin menurun.

\section{Landasan Teori}

Harga saham merupakan nilai yang mampu dibayar oleh investor untuk memperoleh kepemilikan dalam suatu perusahaan. Harga saham dapat dikatakan pula sebagai indikator pengelolaan perusahaan. Harga saham akan mengalami perubahan setiap waktu, hal ini disebut sebagai fluktuasi harga saham. Harga saham dapat bergerak naik juga dapat bergerak turun sesuai dengan permintaan dan penawaran atas saham tersebut. Terjadinya fluktuasi harga saham tentu dipengaruhi oleh faktor-faktor yang ada. Menurut Alwi (2008:87), faktor-faktor yang mempengaruhi harga saham yaitu Faktor Internal terdiri dari (1) Pengumuman tentang pemasaran, produksi, penjualan seperti pengiklanan, rincian kontrak, perubahan harga, penarikan produk baru, laporan produksi, laporan keamanan produk, dan laporan penjualan. (2) Pengumuman pendanaan (financing announcements), seperti pengumuman yang berhubungan dengan ekuitas dan hutang. Pengumuman badan direksi manajemen (management board of director announcements) seperti perubahan dan pergantian direktur, manajemen, dan struktur organisasi. (4) Pengumuman pengambilalihan diversifikasi, seperti laporan merger, investasi ekuitas, laporan take over oleh pengakusisian dan diakuisisi (5) Pengumuman investasi (investment announcements), seperti melakukan ekspansi pabrik, pengembangan riset dan penutupan usaha lainnya (6) Pengumuman ketenagakerjaan (labour announcements), seperti negoisasi baru, kontrak baru, pemogokan dan lainnya (7) Pengumuman laporan keuangan perusahaan, seperti 
peramalan laba sebelum akhir tahun fiskal dan setelah akhir tahun fiskal, Earning Per Share (EPS), Dividen Per Share (DPS), Price Earning Ratio, Net Profit Margin, Return On Assets (ROA), dan lain-lain.

Sedangkan Faktor Eksternal terdiri dari (1) Pengumuman dari pemerintah seperti perubahan suku bunga tabungan dan deposito, kurs valuta asing, inflasi, serta berbagai regulasi dan deregulasi ekonomi yang dikeluarkan oleh pemerintah (2) Pengumuman hukum (legal announcements), seperti tuntutan karyawan terhadap perusahaan atau terhadap manajernya dan tuntutan perusahaan terhadap manajernya (3) Pengumuman industri sekuritas (securities announcements), seperti laporan pertemuan tahunan, insider trading, volume atau harga saham perdagangan, pembatasan/penundaan trading (4) Gejolak politik dalam negeri dan fluktuasi nilai tukar juga merupakan faktor yang berpengaruh signifikan pada terjadinya pergerakan harga saham di bursa efek suatu negara (f) Berbagai isu baik dari dalam dan luar negeri.

Faktor internal merupakan faktor yang muncul dari kondisi perusahaan sendiri sedangkan faktor eksternal muncul dari kondisi di luar perusahaan. Adapun menurut Arifin (2004:116) faktor yang mempengaruhi harga saham antara lain (1) Kondisi fundamental emiten (2) Permintaan dan penawaran (3) Tingkat suku bunga (4) Valuta asing (5) Dana asing dan indek harga saham gabungan (6) News and rumor.

Pendapat yang hampir sama dikemukakan oleh Anoraga dan Pujikarti (2006:60) yang menyatakan bahwa "Hal-hal yang mempengaruhi harga saham adalah kekuatan permintaan dan penawaran(kinerja keuangan, kondisi industri dimana perusahaan tersebut berada), yang bersifat makro (seperti inflasi, suku bunga, nilai tukar) dan faktor nonekonomi (seperti kondisi social,politik luar dan faktor lain)."
Kondisi fundamental emiten serta permintaan dan penawaran dapat digolongkan ke dalam faktor yang muncul dari perusahaan itu sendiri. Maka dapat dikatakan bahwa kondisi fundamental emiten serta permintaan dan penawaran merupakan faktor internal yang dapat mempengaruhi harga saham sedangkan tingkat suku bunga, valuta asing, dana asing, indeks harga saham gabungan, dan news and rumor dapat dikatakan faktor eksternal yang muncul dari luar perusahaan yang bersifat makro.

Dengan demikian dapat dikatakan bahwa harga saham dipengaruhi oleh berbagai macam faktor baik internal maupun eksternal. Faktor internal dapat dilihat melalui kondisi yang terjadi di dalam perusahaan, salah satunya yaitu kondisi fundamental emiten. Kondisi fundamental emiten merupakan kondisi yang erat kaitannya dengan kinerja emitan. Semakin baik kinerja emiten maka semakin baik pula harga saham, sebaliknya apabila kinerja emiten buruk makan akan buruk pula harga saham. Kinerja emiten akan tercermin dalam informasi yang dipublikasikan oleh perusahaan. Dari informasi tersebut kemudian dilakukan analisis fundamental untuk dapat melihat bagaimana kondisi kinerja emiten yang akan berpengaruh terhadap harga saham.

Menurut Sutrisno (2005:331) “Analisis fundamental merupakan pendekatan analisis harga saham yang menitikberatkan pada kinerja perusahaan yang mengeluarkan saham dan analisis ekonomi yang akan mempengaruhi masa depan perusahaan." Baik investor maupun perusahaan perbankan itu sendiri dapat melakukan analisis fundamental ini untuk memprediksi harga saham di masa yang akan datang. Analisis fundamental dilakukan untuk menganalisis harga saham melalui kinerja perusahaan itu sendiri. Kinerja keuangan merupakan salah satu kinerja perusahaan yang dapat digunakan untuk menganalisis harga saham. Kinerja keuangan perbankan terdiri dari rasio-rasio keuangan perbankan. Dengan demikian melalui analisis fundamental dapat dilihat bagaimana pengaruh kinerja keuangan terhadap harga saham.

Kinerja keuangan perbankan dapat diukur dengan melalui beberapa indikator. Menurut Peraturan Bank Indonesia No. 


\section{JURNAL PENDIDIKAN AKUNTANSI DAN KEUANGAN}

Vol. 5, No. 1, [Januari-Juni], 2017 : 39-54

13/1/2011 tentang Penilaian Tingkat Kesehatan Bank Umum bahwa penilaian tingkat kesehatan bank dalam hal ini adalah kinerja keuangan bank mencakup penilaian terhadap indikator profil risiko (risk profile), Good Corporate Governance (GCG), permodalan (capital), dan rentabilitas (earnings). Selanjutnya indikator penilaian tingkat kesehatan bank yang digunakan adalah profil risiko (risk profile) yang diwakili oleh risiko kredit dan risiko likuiditas, rentabilitas (earning), dan permodalan (capital). Sesuai dengan Surat Edaran Bank Indonesia No. 13/24/DPNP rasio-rasio keuangan yang digunakan dalam mengukur indikator-indikator di atas ialah permodalan dapat diukur dengan Capital Adequacy Ratio (CAR), risiko kredit dapat diukur melalui rasio Non Performing Loan (NPL), risiko likuiditas dapat diukur dengan Loan to Deposit Ratio (LDR), dan rentabilitas dapat diukur dengan Return On Asset (ROA).

Capital Adequacy Ratio (CAR) sering disebut juga dengan kebutuhan penyediaan modal minimum. Sesuai dengan ketentuan Bank Indonesia, suatu bank dikatakan sehat apabalia memiliki rasio CAR minimal delapan persen (8\%). Semakin tingginya CAR maka akan menunjukkan kemampuan bank dalam menanggulangi risiko yang semakin baik dan semakin besar pula peluang bank untuk menyalurkan kredit. Sehingga akan semakin menumbuhkan rasa kepercayaan stakeholder atau para investor pada kelangsungan operasional bank.

Non Performing Loan (NPL) menunjukkan kinerja bank dalam penyaluran kredit. NPL dapat diartikan sebagai pinjaman yang mengalami kesulitan dalam pelunasannya atau dapat dikatakan juga sebagai kredit bermasalah atau macet. Semakin tinggi NPL suatu bank maka akan mencerminkan kinerja dalam penyaluran kredit yang tidak baik. Apabila penyaluran kredit suatu bank tidak baik maka risiko terjadinya kredit bermasalah pun akan menjadi cukup tinggi. Hal tersebut akan mempengaruhi bank dalam mendapatkan laba. Tetapi apabila nilai NPL semakin rendah maka mencerminkan kinerja dalam penyaluran kredit yang baik, hal tersebut akan meningkatkan dalam perolehan laba bank.
Loan to Deposit Ratio (LDR) merupakan perbandingan antara kredit yang disalurkan dengan dana dari pihak ketiga yang telah dihimpun oleh bank berupa giro, tabungan, dan deposito. Apablia LDR berada pada kisaran 78\%-92\% maka akan dikatakan baik. Semakin tinggi LDR maka akan memberikan indikasi bahwa bank telah memaksimalkan dana dalam bentuk kredit tetapi akan menunjukkan semakin rendahnya pula tingkat likuiditas bank. Sebaliknya, rendahnya LDR akan menunjukkan bank yang likuid dengan kapasitas dana yang berlebih tetapi bank dinilai kurang baik dalam menjalankan fungsinya sebagai lembaga intermediasi. Sehingga LDR harus dijaga dalam batas yang telah ditentukan agar bank berada dalam kondisi sehat.

Return On Asset (ROA) merupakan rasio untuk mengukur rentabilitas bank. ROA digunakan untuk mengukur bagaimana kemampuan bank dalam memperoleh keuntungan (laba). ROA ini mencerminkan bagaimana bank menghasilkan laba melalui kemampuan aktiva yang dimiliki. Semakin tinggi ROA maka semakin tinggi pula keuntungan yang dicapai oleh bank. Bank Indonesia telah menentukan batas minimum untuk ROA adalah sebesar 1,5\%. Apabila bank memiliki ROA lebih dari $1,5 \%$ maka dapat dikatakan bahwa bank tersebut produktif dalam mengelola aktiva yang dimilikinya.

Penelitian sebelumnya yang memiliki tema sentral dengan penelitian ini yang telah dilakukan oleh Wulandari (2015) menyatakan bahwa "CAR dan NPL tidak memiliki pengaruh yang signifikan terhadap harga saham sedangkan LDR dan ROA memiliki pengaruh yang signifikan terhadap harga saham". Dan menurut penelitian yang dilakukan oleh Satria dan Hatta (2015) mengindikasikan bahwa "Secara parsial, LDR, CAR dan ROE berpengaruh signifikan terhadap harga saham. Sementara, NPL tidak berpengaruh terhadap harga saham". Sedangkan penelitian yang dilakukan oleh Ulfa dan Budianto (2014) menyatakan bahwa "Loan to Deposit Ratio (LDR), Return On Assets (ROA), dan Capital Adequacy Ratio (CAR) berpengaruh tidak signifikan terhadap harga saham". Adapun jurnal asing yang melakukan penelitian dengan tema yang sama yaitu penelitian yang dilakukan 
oleh Inyiama (2015) menyatakan bahwa "ROA tidak memiliki pengaruh yang signifikan terhadap harga saham". Jurnal asing lain yang melakukan penelitian serupa oleh Shah et al (2013) mengemukakan bahwa "It has been concluded on the basis of analysis that three variables; earning per share, return on assets and return on capital employed are significant while other two variables; dividend payout ratio and return on equity have no statistically significant effect on the share price." Yang artinya bahwa berdasarkan analisis yang dilakukan telah disimpulkan bahwa tiga variabel yaitu Earning Per Share, Return On Assets dan Return On Capital berpengaruh signifikan dibandingkan dengan dua variable lainnya yaitu Dividend Payout Ratio dan Return On Equity, sehingga dapat disimpulkan bahwa dalam penelitian tersebut ROA berpengaruh signifikan terhadap harga saham.

\section{Metode Penelitian}

Metode penelitian yang digunakan dalam penelitian ini adalah metode deskriptif dan verifikatif. Metode deskriptif menurut Nazir (2014:43), "Metode deskriptif adalah metode penelitian untuk membuat gambaran mengenai situasi atau kejadian, sehingga metode ini mengadakan akumulasi data dasar belaka". Sedangkan metode verifikatif menurut Sugiyono (2012:8), "Metode verifikatif diartikan sebagai penelitian yang dilakukan terhadap populasi atau sampel tertentu dengan tujuan untuk menguji hipotesis yang telah ditetapkan."

\section{Populasi dan Sampel}

Populasi dalam penelitian ini yaitu Perusahaan Sub Sektor Perbankan yang terdaftar di Bursa Efek Indonesia sejumlah 43 bank umum konvensional. Dalam pengambilan sampel pada penelitian ini digunakan teknik purposive sampling. Adapun kriteria-kriteria tersebut adalah Bank umum konvensional yang terdaftar di Bursa Efek Indonesia serta menerbitkan laporan keuangan pada tahun 2013-2016. Bank umum konvensional yang cenderung mengalami penurunan harga saham dari tahun 2013-2016. Berdasarkan kriteria yang telah ditetapkan di atas maka didapatkan sampel berjumlah 10 bank umum konvensional dengan 40 data observasi.

\section{Pengujian Hipotesis}

Data penelitian akan menghasilkan estimasi yang bias apabila tidak memenuhi asumsi regresi. Penerapan regresi berganda yang baik memiliki estimasi yang bersifat BLUE (Best, Linier, Unbiased, Estimator). Agar data dapat dikatakan bersifat BLUE maka uji asumsi klasik yang digunakan dalam penelitian ini adalah Uji Normalitas, Uji linieritas, Uji multikoliniearitas, Uji heteroskedastisitas, Uji Autokorelasi.

Analisis dilakukan untuk mengetahui apakah ada hubungan sebab akibat antar variabel atau seberapa besar pengaruh variabel independen terhadap variabel dependen. Dalam penelitian ini analisis regresi linier berganda dilakukan untuk menerangkan besarnya pengaruh Capital Adequacy Ratio (CAR), Non Performing Loan (NPL), Loan to Deposit Ratio (LDR) dan Return On Assets (ROA) terhadap harga saham bank. Adapun data yang digunakan dalam penelitian ini adalah data panel, sehingga dalam penelitian ini analisis yang digunakan adalah analisis regresi linier berganda dengan data panel. Selanjutnya akan dilakukan pengujian dengan menggunakan eviews 9 .

Pengujian hipotesis dengan uji $\mathrm{F}$ menurut Sudjana (2003:90) "Digunakan untuk meyakinkan diri apakah regresi (berbentuk linear) yang didapat berdasarkan penelitian ada artinya bila dipakai untuk membuat kesimpulan mengenai hubungan sejumlah peubah yang sedang dipelajari." Kesimpulan uji statistik F dapat diketahui dari taraf signifikansi 5\%.

Uji statistik $\mathrm{t}$ digunakan untuk menguji satu indikator variabel independen secara individu dalam menjelaskan variasi variabel dependen. Dan menunjukkan tingkat signifikansi pengaruh variabel $\mathrm{X}$ terhadap variabel $\mathrm{Y}$. Adapun langkah-langkah Uji statistik $t$ adalah sebagai berikut:

Merumuskan Hipotesis. Permodelan rumusan hipotesis dalam uji $t$ ini adalah sebagai berikut:

$\mathrm{H}_{0}: \beta_{1}=0$ CAR tidak berpengaruh terhadap harga saham 


\section{JURNAL PENDIDIKAN AKUNTANSI DAN KEUANGAN}

Vol. 5, No. 1, [Januari-Juni], 2017 : 39-54

$\mathrm{H}_{1}: \beta_{1}>0$ CAR berpengaruh positif terhadap harga saham

a. Risiko Kredit

$\mathrm{H}_{0}: \beta_{2}=0$ NPL tidak berpengaruh terhadap harga saham

$\mathrm{H}_{1}: \beta_{2}<0$ NPL berpengaruh negatif terhadap harga saham

b. Risiko Likuiditas

$\mathrm{H}_{0}: \beta_{3}=0$ LDR tidak berpengaruh terhadap harga saham

$\mathrm{H}_{1}: \beta_{3}<0$ LDR berpengaruh negatif terhadap harga saham

c. Rentabilitas

$\mathrm{H}_{0}: \beta_{4}=0$ ROA tidak berpengaruh terhadap harga saham

$\mathrm{H}_{1}: \beta_{4}>0$ ROA berpengaruh positif terhadap harga saham

Menentukan taraf nyata (a) 5\%, Meregresi masing-masing variabel independen, terhadap variabel dependen dengan regresi multiple.

Kriteria pengujian yaitu Uji pihak kiri Jika nilai $\mathrm{t}_{\text {hitung }}>$ nilai $\mathrm{t}_{\text {tabel }}$ maka $\mathrm{H}_{0}$ diterima dan $\mathrm{H}_{1}$ ditolak, Jika nilai $\mathrm{t}_{\text {hitung }} \leq$ nilai $\mathrm{t}_{\text {tabel }}$ maka $\mathrm{H}_{0}$ ditolak dan $\mathrm{H}_{1}$ diterima. Uji pihak kanan, Jika nilai $\mathrm{t}_{\text {hitung }}>$ nilai $\mathrm{t}_{\text {tabel }}$ maka $\mathrm{H}_{0}$ ditolak dan $\mathrm{H}_{1}$ diterima, Jika nilai $\mathrm{t}$ hitung $\leq$ nilai $\mathrm{t}_{\text {tabel }}$ maka $\mathrm{H}_{0}$ diterima dan $\mathrm{H}_{1}$ ditolak

Membuat kesimpulan. Selanjutnya nilai $t_{\text {hitung }}$ dibandingkan dengan $t_{\text {tabel }}$ dengan ketentuan apabila $t_{\text {hitung }}$ lebih besar dari $t_{\text {tabel }}$ maka $\mathrm{H}_{0}$ ditolak dan $\mathrm{H}_{1}$ diterima yang berarti terdapat pengaruh antara variabel independen terhadap variabel dependen.Sebaliknya jika $t_{\text {hitung }}$ lebih kecil dari $t_{\text {tabel }}$ maka $\mathrm{H}_{0}$ diterima dan $\mathrm{H}_{1}$ ditolak yang berarti tidak terdapat pengaruh antara variabel independen terhadap variabel dependen.

\section{Hasil dan Pembahasan \\ Pengaruh Permodalan (Capital Adequacy Ratio) Terhadap Harga Saham}

Berdasarkan analisis deskriptif mengenai harga saham sebelumnya, selama tahun 2013-2016 harga saham penutupan tahunan bank umum konvensional terus mengalami pergerakan dan memperoleh rata- rata sebesar Rp 1.177,20. Setiap bank memiliki harga saham yang berbeda-beda. Dari 10 bank umum konvensional yang menjadi sampel pada penelitian ini, terdapat 3 atau sebesar $30 \%$ bank yang memiliki harga saham diatas rata-rata. Sedangkan 7 bank lainnya atau sebesar $70 \%$ memiliki harga saham dibawah rata-rata. Perbedaan harga saham yang terjadi dapat disebabkan oleh beberapa faktor, baik internal maupun eksternal. Dalam penelitian ini faktor yang diteliti merupakan faktor yang berasal dari internal yaitu faktor kondisi fundamental emiten yang dicerminkan oleh kinerja keuangan. Salah satu komponen kinerja keuangan yang diteliti adalah permodalan.

Permodalan merupakan hal yang penting dalam membangun sebuah usaha. Modal berfungsi untuk membiayai operasi perusahaan, sebagai alat ekspansi usaha, sebagai instrument untuk mengantisipasi risiko. Dalam sebuah usaha peran modal sangat penting dalam menampung risiko. Modal bank merupakan instrumen dalam menunjang kebutuhan operasi. Bank memiliki kewajiban untuk menyediakan modal minimum. Penyediaan modal minimum bank kemudian dapat diukur dengan kecukupan modal dengan indikator Capital Adequacy Ratio (CAR).

Bank dengan nilai CAR tinggi dinilai telah menyediakan modal yang memadai untuk menunjang kebutuhan operasi sehingga dapat menampung risiko yang terjadi. Dalam penelitian ini nilai CAR semua bank yang menjadi sampel telah menyediakan modal di atas standar penyediaan modal minimum yaitu senilai $8 \%$. Bank yang telah menyediakan modal diatas standar penyediaan modal minimum akan meningkatkan rasa kepercayaan nasabah serta investor sebagai pemilik dana, sehingga nasabah dan investor akan memiliki rasa nyaman serta aman dalam menanamkan dananya kepada bank. Semakin tinggi penyediaan modal minimum bank, maka semakin menarik investor untuk menanamkan modal. Dengan begitu permintaan akan saham terus bergerak naik, harga saham bank pun akan terus meningkat seiring dengan meningkatnya permintaan saham bank.

Untuk melihat adanya pengaruh permodalan terhadap harga saham, maka dilakukan studi empiris. Dari pengujian yang 
telah dilakukan diperoleh hasil nilai koefisien regresi dari variabel permodalan yang diukur dengan Capital Adequacy Ratio (CAR) adalah sebesar 0,076524. Artinya, nilai tersebut menunjukkan bahwa CAR berpengaruh positif terhadap harga saham. Apabila CAR mengalami kenaikan sebesar $1 \%$ maka harga saham akan naik sebesar $0,076524 \%$, dengan asumsi variabel lain dianggap tetap.

Selanjutnya dilakukan pengujian hipotesis keberartian regresi menggunakan uji $\mathrm{F}$. Dari pengujian yang telah dilakukan, maka diperoleh hasil $\mathrm{F}_{\text {hitung }}>\mathrm{F}_{\text {tabel }}$ dengan nilai sebesar 4,755251 > 2,64 maka $\mathrm{H}_{0}$ ditolak. Sehingga dapat disimpulkan bahwa permodalan secara signifikan berpengaruh terhadap harga saham, artinya dapat digunakan untuk membuat suatu kesimpulan. Apabila regresi dikatakan berarti dan dapat digunakan dalam membuat suatu kesimpulan selanjutnya dilakukan uji keberartian koefisien regresi menggunakan uji t. Dari pengujian yang telah dilakukan maka didapatkan hasil $t_{\text {hitung }} 3,014638>t_{\text {tabel }} 1,68957$ dengan nilai signifikansi 0,0048 . Berdasarkan nilai tersebut maka keputusan yang diambil adalah $\mathrm{H}_{0}$ ditolak dan $\mathrm{H}_{1}$ diterima. Sehingga dapat dikatakan bahwa permodalan memiliki berpengaruh positif dan signifikan terhadap harga saham. Artinya, setiap modal bank meningkat maka harga saham akan mengalami kenaikan.

Bank dengan CAR yang tinggi memiliki kemampuan yang baik dalam menampung risiko yang akan terjadi. Hal tersebut akan membuat bank memiliki risiko rendah. Bank dengan risiko yang rendah dinilai memiliki kinerja keuangan yang baik sehingga akan lebih menarik perhatian investor untuk menanamkan dananya kepada bank. Menurut Siamat (2005:84) bahwa “...dengan CAR tinggi berarti bank tersebut semakin solvable bank memiliki modal yang cukup guna menjalankan usahanya sehingga akan meningkatkan keuntungan yang diperoleh sehingga akan terjadi kenaikan pada harga saham." Secara teoritis pada dasarnya semakin tinggi CAR maka semakin tinggi pula harga saham. Sejalan dengan penelitian Sambul (2016) yang menyatakan bahwa semakin tinggi CAR maka akan semakin tinggi pula harga saham, karena bank yang mempunyai CAR yang tinggi berarti bank tersebut mempunyai modal yang cukup untuk melakukan kegiatan usahanya dan cukup pula menanggung risiko apabila bank tersebut dilikuidasi.

Dengan demikian hasil penelitian ini menyatakan bahwa permodalan berpengaruh positif secara signifikan terdahap harga saham. Penelitian ini juga mendukung penelitian yang dilakukan oleh Saptorini Dyah Lestari (2015) yang menyatakan bahwa CAR berpengaruh secara signifikan terhadap harga saham. Juga penelitian yang dilakukan oleh Haeryetti (2012) yang menyatakan bahwa CAR berpengaruh signifikan terhadap harga saham.

\section{Pengaruh Risiko Kredit (Non Performing Loan) Terhadap Harga Saham}

Berdasarkan penjelasan mengenai analisis deskriptif harga saham sebelumnya, dari 10 bank umum konvensional yang menjadi sampel dalam penelitian ini terdapat 3 atau sebesar $30 \%$ bank yang memiliki harga saham diatas rata-rata. Sedangkan 7 bank lainnya atau sebesar $70 \%$ memiliki harga saham dibawah rata-rata. Faktor penyebab yang diteliti yaitu faktor kondisi fundamental emiten yang dicerminkan oleh kinerja keuangan. Setelah sebelumnya dilakukan penelitian terhadap komponen permodalan, selanjutnya komponen kinerja keuangan yang diteliti adalah risiko kredit.

Risiko kredit terjadi akibat adanya kegagalan debitur atau pihak lain dalam memenuhi kewajiban kepada bank. Risiko kredit dapat dilihat melalui besarnya kredit bermasalah atau macet yang dimiliki oleh bank. Kredit bermasalah dapat melihat kemampuan bank dalam mengelola kredit. Apabila bank mengelola kredit dengan baik maka akan semakin kecil risiko terjadinya kredit bermasalah. Semakin rendahnya risiko kredit bermasalah maka kinerja keuangan bank dinilai semakin baik. Tingginya risiko kredit bermasalah akan mengakibatkan semakin tingginya bunga kredit yang akan menurunkan pendapatan dan laba bank. Semakin tingginya risiko yang akan terjadi akan mengindikasikan bahwa bank memiliki kinerja keuangan yang buruk. Investor tentu akan menghindari perusahaan yang memiliki risiko tinggi, 


\title{
JURNAL PENDIDIKAN AKUNTANSI DAN KEUANGAN
}

\author{
Vol. 5, No. 1, [Januari-Juni], 2017 : 39-54
}

akibatnya investor akan enggan untuk menanamkan dananya kepada bank yang memiliki risiko tinggi. Semakin rendahnya minat investor untuk berinvestasi maka akan menurunkan permintaan saham yang berakibat pada menurunnya harga saham.

Untuk melihat adanya pengaruh risiko kredit terhadap harga saham, maka dilakukan studi empiris. Dari pengujian yang telah dilakukan diperoleh hasil nilai koefisien regresi dari variabel risiko kredit yang diukur dengan Non Performing Loan (NPL) adalah sebesar 0,000932 . Artinya, nilai tersebut menunjukkan bahwa NPL memiliki pengaruh negatif terhadap harga saham. Apabila NPL mengalami kenaikan sebesar $1 \%$ maka harga saham akan mengalami penurunan sebesar $0,000932 \%$, dengan asumsi variabel lain dianggap tetap.

Selanjutnya dilakukan pengujian hipotesis keberartian regresi menggunakan uji $\mathrm{F}$. Dari pengujian yang telah dilakukan, maka diperoleh hasil $\mathrm{F}_{\text {hitung }}>\mathrm{F}_{\text {tabel }}$ dengan nilai sebesar 4,755251 > 2,64 maka $\mathrm{H}_{0}$ ditolak. Sehingga dapat disimpulkan bahwa risiko kredit bepengaruh signifikan terhadap harga saham, artinya dapat digunakan untuk membuat suatu kesimpulan. Apabila regresi dikatakan berarti dan dapat digunakan dalam membuat suatu kesimpulan selanjutnya dilakukan uji keberartian koefisien regresi menggunakan uji t. Dari pengujian yang telah dilakukan diperoleh hasil $t_{\text {hitung }}-2,496652 \leq \mathrm{t}_{\text {tabel }}-1,68957$ dengan nilai signifikansi 0,0174 . Berdasarkan nilai tersebut maka keputusan yang diambil adalah $\mathrm{H}_{0}$ ditolak dan $\mathrm{H}_{1}$ diterima. Sehingga dapat dikatakan bahwa risiko kredit memiliki berpengaruh negatif dan signifikan terhadap harga saham. Artinya, setiap risiko kredit bank meningkat maka harga saham akan mengalami penurunan.

Tingginya NPL suatu bank mengindikasikan bahwa bank kurang baik dalam mengelola kreditnya sehingga bank berisiko tinggi dalam mengalami kredit bermasalah. Tingginya risiko kredit bermasalah suatu bank maka mencerminkan kinerja keuangan yang buruk. Menurut Riyadi (2006:161) bahwa "Semakin besar tingkat NPL menunjukkan bahwa bank tersebut tidak professional dalam pengelolaan kreditnya." Hal tersebut akan menurunkan minat investor untuk menanamkan dananya kepada bank. Turunnya minat investor untuk berinvestasi menyebabkan permintaan saham menurun. Permintaan saham yang menurun akan mengakibatkan harga saham mengalami penurunan. Seperti yang dikemukakan oleh Sambul (2016) dalam penelitiannya bahwa semakin banyak kredit bermasalah maka kesempatan bank dalam mendapatkan profit akan semakin sedikit sehingga dengan NPL yang tinggi pada perbankan investor tidak akan tertarik untuk membeli saham karena keuntungan yang akan di dapat kecil. Dengan menurunnya minat investor untuk berinvestasi maka harga saham bank pun akan mengalami penurunan.

Dengan demikian hasil penelitian ini menyatakan bahwa risiko kredit secara signifikan berpengaruh negatif terdahap harga saham. Penelitian ini juga mendukung penelitian yang dilakukan oleh Saptorini Dyah Lestari (2015) yang menyatakan bahwa NPL secara signifikan berpengaruh terhadap harga saham. Penelitian yang juga dilakukan oleh Firas $\mathrm{Na}$ 'el Rawhi Hashem (2017) menyatakan bahwa NPL berpengaruh signifikan terhadap harga saham.

\section{Pengaruh Risiko Likuiditas (Loan to Deposit Ratio) Terhadap Harga Saham}

Berdasarkan analisis deskriptif mengenai harga saham, 3 dari 10 bank umum konvensional yang menjadi sampel dalam penelitian atau sebesar $30 \%$ bank memiliki harga saham diatas rata-rata. Sedangkan 7 bank lainnya atau sebesar $70 \%$ memiliki harga saham dibawah rata-rata. Komponen kinerja keuangan yang diteliti selanjutnya adalah risiko likuiditas. Risiko likuiditas terjadi akibat ketidakmampuan bank dalam memenuhi kewajiban yang jatuh tempo. Bank yang memiliki kinerja baik mampu menjaga keseimbangan antara pemberian kredit dengan kewajiban pengembalian dana atas modal yang telah disetor pihak ketiga. Risiko likuiditas kemudian dapat diukur melalui Loan to Deposit Ratio (LDR).

Untuk melihat adanya pengaruh risiko kredit terhadap harga saham, maka dilakukan studi empiris. Dari pengujian yang telah dilakukan diperoleh hasil nilai koefisien regresi dari variabel risiko kredit yang diukur dengan 
Loan to Deposit Ratio (LDR) adalah sebesar 0,357918. Artinya, nilai tersebut menunjukkan bahwa LDR memiliki pengaruh positif terhadap harga saham. Sehingga apabila LDR mengalami kenaikan sebesar $1 \%$ maka harga saham akan mengalami kenaikan sebesar 0,357918\%, dengan asumsi variabel lain dianggap tetap.

Selanjutnya dilakukan pengujian hipotesis keberartian regresi menggunakan uji F. Dari pengujian yang telah dilakukan, maka diperoleh hasil $\mathrm{F}_{\text {hitung }}>\mathrm{F}_{\text {tabel }}$ dengan nilai sebesar 4,755251 > 2,64 maka $\mathrm{H}_{0}$ ditolak. Sehingga dapat disimpulkan bahwa risiko likuiditas berpengaruh signifikan terhadap harga saham, artinya dapat digunakan untuk membuat suatu kesimpulan. Apabila regresi dikatakan berarti dan dapat digunakan dalam membuat suatu kesimpulan selanjutnya dilakukan uji keberartian koefisien regresi menggunakan uji t. Dari pengujian yang telah dilakukan diperoleh hasil $\mathrm{t}_{\text {hitung }} 1,944726 \leq \mathrm{t}_{\text {tabel }}-1,68957$ dengan nilai signifikansi $0,0599>0,05$. Berdasarkan nilai tersebut maka keputusan yang diambil adalah risiko likuiditas berpengaruh positif tidak signifikan terhadap harga saham. Artinya, naik turunnya LDR berpengaruh kepada harga saham tetapi tidak memiliki arti sehingga tidak dapat dijadikan suatu unsur penting dalam penentuan perubahan harga saham.

Hasil penelitian ini tidak mendukung hipotesis awal penelitian yang menyatakan bahwa risiko likuiditas berpengaruh negatif terhadap harga saham. Hal tersebut juga tidak sesuai dengan teori yang dikemukakan oleh Rivai (2012:153) yang menyatakan bahwa "Semakin tinggi rasio LDR, memberikan indikasi rendahnya kemampuan likuidias bank yang bersangkutan." Selain itu Dendawijaya (2000:118) juga menyatakan bahwa "Semakin tinggi rasio ini semakin rendah pula tingkat likuiditas bank." Artinya semakin tinggi rasio LDR bank maka bank dinilai semakin tidak likuid. Bank dengan tingkat likuid rendah dinilai tidak memiliki cukup dana untuk membiayai kredit sehingga mengakibatkan risiko kredit bermasalah yang tinggi dengan demikian investor enggan untuk berinvestasi. Penolakan hipotesis dalam variabel ini diduga pula karena terdapat kesalahan peneliti dalam mengambil teori. Menurut Riyadi (2006:165) menyatakan bahwa "Semakin tinggi LDR maka laba perusahaan semakin meningkat dengan asumsi bank tersebut mampu menyalurkan kredit dengan efektif." Artinya, bagi sebagian investor bank dengan LDR tinggi dinilai telah menyalurkan kredit secara maksimal sehingga akan mendapatkan laba yang maksimal pula, dengan begitu investor akam mendapatkan keuntungan yang tinggi pula. Selain itu batas ketentuan yang ditetapkan Bank Indonesia sebesar 72\%-98\% membuat LDR mempunyai dua sisi arah karena apabila LDR semakin tinggi maka bank dinilai memiliki likuiditas yang rendah tetapi bank dipandang dapat melaksanakan fungsi intermediasi dengan baik melalui penyaluran kredit. Sehingga investor melihat apabila bank telah melakukan penyaluran kredit dengan maksimal maka keuntungan yang akan didapatkan oleh bank semakin tinggi. Tetapi apabila kita melihat dari sisi risiko, bank yang melakukan penyaluran kredit secara maksimal dengan memiliki likuiditas yang rendah mempunyai risiko tinggi dalam terjadinya kredit bermasalah. Sehingga dengan tingginya penyaluran kredit yang disalurkan bank beberapa investor yang melihat hal tersebut sebagai keuntungan akan tertarik untuk menanamkan dananya. Sebaliknya, apabila nilai LDR rendah maka bank akan dinilai memiliki likuiditas yang tinggi karena memiliki cukup dana untuk memenuhi kewajiban-kewajiban dalam pengembalian dana kepada investor. Tetapi bank dinilai tidak menjalankan fungsi intermediasinya dengan baik karena bank tidak melakukan penyaluran kredit secara maksimal. Untuk sebagian investor, bank dengan dana yang mencukupi lebih menarik dibandingkan dengan bank yang melakukan penyaluran kredit secara maksimal. Bank dengan dana yang mencukupi dinilai dapat memenuhi kewajiban dalam pengembalian dana investor. Sehingga LDR tidak dapat dijadikan salah satu unsur yang penting dalam pengambilan keputusan investasi, sehingga LDR berpengaruh dan tidak signifikan terhadap harga saham.

Dengan demikian hasil dari penelitian ini menyatakan bahwa risiko likuiditas berpengaruh dan tidak signifikan terhadap harga saham. Hasil penelitian ini sejalan dengan 


\section{JURNAL PENDIDIKAN AKUNTANSI DAN KEUANGAN}

Vol. 5, No. 1, [Januari-Juni], 2017 : 39-54

penelitian yang dilakukan oleh Haryetti (2012) yang menyatakan bahwa LDR tidak berpengaruh signifikan terhadap harga saham. Kemudian penelitian yang dilakukan oleh Saptorini Dyah Lestari (2015) menyatakan bahwa LDR tidak mempunyai pengaruh signifikan terhadap harga saham.

\section{Pengaruh Rentabilitas (Return On Asset) Terhadap Harga Saham}

Dari penjelasan telah disebutkan bahwa $30 \%$ harga saham bank umum konvensional berada di bawah rata-rata, sedangkan $70 \%$ lainnya sudah memiliki harga saham di atas ratarata. Rata-rata harga saham bank umum konvensional selama tahun 2013-2016 adalah sebesar Rp 1.177,20. Rentabilitas adalah komponen kinerja keuangan yang akan diteliti selanjutnya. Rentabilitas merupakan kemampuan bank dalam menghasilkan laba dari aktiva yang dimilikinya. Rentabilitas melihat sejauh mana bank memaksimalkan aktiva untuk memperoleh laba. Rentabilitas dapat diukur dengan Return On Asset (ROA).

Untuk melihat adanya pengaruh rentabilitas terhadap harga saham, maka dilakukan studi empiris. Dari pengujian yang telah dilakukan diperoleh hasil nilai koefisien regresi dari variabel rentabilitas yang diukur dengan Return On Asset (ROA) adalah sebesar 0,000320. Artinya, nilai tersebut menunjukkan bahwa ROA memiliki pengaruh positif terhadap harga saham. Sehingga apabila ROA mengalami kenaikan sebesar $1 \%$ maka harga saham akan mengalami kenaikan sebesar 0,000320\%, dengan asumsi variabel lain dianggap tetap.

Selanjutnya dilakukan pengujian hipotesis keberartian regresi menggunakan uji F. Dari pengujian yang telah dilakukan, maka diperoleh hasil $\mathrm{F}_{\text {hitung }}>\mathrm{F}_{\text {tabel }}$ dengan nilai sebesar 4,755251 > 2,64 maka $\mathrm{H}_{0}$ ditolak. Sehingga dapat disimpulkan bahwa rentabilitas berpengaruh signifikan terhadap harga saham, artinya dapat digunakan untuk membuat suatu kesimpulan. Apabila regresi dikatakan berarti dan dapat digunakan dalam membuat suatu kesimpulan selanjutnya dilakukan uji keberartian koefisien regresi menggunakan uji t. Dari pengujian yang telah dilakukan diperoleh hasil $t_{\text {hitung }} 3,596826 \leq \mathrm{t}_{\text {tabel }} 1,68957$ dengan nilai signifikansi 0,00010. Berdasarkan nilai tersebut maka keputusan yang diambil adalah $\mathrm{H}_{0}$ ditolak dan $\mathrm{H}_{1}$ diterima. Sehingga dapat dikatakan bahwa rentabilitas memiliki pengaruh positif secara signifikan terhadap harga saham. Artinya, setiap ROA mengalami kenaikan maka harga saham akan meningkat.

Bank yang memiliki kemampuan dalam menghasilkan laba yang tinggi akan lebih menarik investor untuk menanamkan dananya kepada bank. Semakin baik kemampuan bank dalam menghasilkan laba maka investor percaya akan semakin tinggi pula keuntungan di masa depan yang akan didapatkan. Seperti yang dikemukakan oleh Syamsuddin (2007:63) bahwa "Para pemegang saham menaruh perhatian utama pada tingkat keuntungan baik sekarang maupun masa yang akan datang karena tingkat keuntungan ini akan mempengaruhi harga saham-saham yang mereka miliki." Sehingga bank dengan ROA tinggi akan meningkatkan rasa ketertarikan investor untuk menanamkan dana. Dengan meningkatnya minat investor untuk berinvestasi kepada bank akan menyebabkan peningkatan pada permintaan saham yang mengakibatkan meningkat pula harga saham. Sehingga semakin tinggi ROA semakin meningkat pula harga saham.

Dapat disimpulkan hasil dari penelitian ini adalah ROA memiliki pengaruh positif secara signifikan terhadap harga saham. Sejalan dengan penelitian yang dilakukan oleh Wulandari (2015) bahwa ROA memiliki pengaruh yang signifikan terhadap harga saham. Selain itu penelitian yang dilakukan oleh Zuliarni (2012) menyatakan bahwa ROA berpengaruh signifikan terhadap harga saham.

\section{Kesimpulan dan Saran Kesimpulan}

Berdasarkan hasil pembahasan dan penelitian dari 10 sampel bank umum konvensional yang tercatat di Bursa Efek Indonesia tahun 2013 sampai tahun 2016, maka dapat ditarik kesimpulan sebagai yaitu (1) Gambaran dari Permodalan Bank Umum Konvensional mengalami fluktuasi dengan kecenderungan menurun dari tahun 2013- 
2015 dan mengalami kenaikan pada tahun 2016. Risiko kredit Bank Umum Konvensional mengalami kenaikan setiap tahunnya. Risiko kredit Bank Umum Konvensional mengalami penurunan pada tahun 2013 dan tahun 2015 serta mengalami kenaikan pada tahun 2014 dan 2016. Rentabilitas Bank Umum Konvensional cenderung mengalami penurunan. Berdasarkan penelitian yang telah dilakukan diperoleh hasil bahwa permodalan secara signifikan berpengaruh positif terhadap harga saham. (3) Berdasarkan penelitian yang telah dilakukan diperoleh hasil bahwa risiko kredit secara signifikan berpengaruh negatif terhadap harga saham.

Berdasarkan penelitian yang telah dilakukan diperoleh hasil bahwa risiko likuiditas berpengaruh positif tidak signifikan terhadap harga saham. (5) Berdasarkan penelitian yang telah dilakukan diperoleh hasil bahwa rentabilitas secara signifikan berpengaruh positif terhadap harga saham.

\section{Saran}

Berdasarkan hasil penelitian dan kesimpulan yang telah diuraikan sebelumnya, terdapat keterbatasan dalam penelitian ini dalam beberapa hal diantaranya adalah variabel penelitian yang digunakan, waktu penelitian, objek penelitian serta metode yang digunakan dalam penelitian. Adapun peneliti dapat memberikan saran yaitu (1) Bagi bank yang memiliki Capital Adequacy Ratio di atas standar kententuan Bank Indonesia, disarankan untuk mempertahankan konsistensinya dalam menyediakan modal minimum. Hal tersebut dapat dilakukan dengan cara meningkatkan modal bank melalui penyisihan laba serta penimbunan dividen dengan tidak membagikan dividen. Dengan meningkatkan modal maka bank akan mampu menyediakan modal minimum semakin besar sehingga akan meningkatkan rasio CAR bank. (2) Bagi bank yang memiliki nilai Non Performing Loan di bawah nilai ketentuan yang telah ditetapkan Bank Indonesia yaitu tidak melebihi 5\% disarankan agar tetap mempertahankan pengelolaan kreditnya agar risiko terjadinya kredit bermasalah semakin minim. Sehingga tingkat kepercayaan investor kepada bank semakin baik dan investor tetap menanamkan modalnya pada bank. Bagi bank yang memiliki non performing loan di atas 5\% disarankan untuk meningkatkan kemampuan dalam mengelola kredit. Selain itu risiko terjadinya kredit bermasalah dapat diturunkan dengan cara memberikan pengawasan lebih terhadap permohonan kredit yang diajukan nasabah, bank diharapkan dapat lebih menganalisis kemampuan nasabah dalam pengembalian kredit sehingga hal tersebut dapat meminimalisir terjadinya kredit bermasalah. Penurunan tingkat suku bunga yang diberikan dalam penyaluran kredit kepada nasabah juga dapat membantu menurunkan risiko terjadinya nasabah yang kesulitan dalam membayar pengembalian kredit. Pengelolaan kredit yang baik akan meminimalisir terjadinya kredit bermasalah dan menurunkan rasio NPL. (3) Bagi bank yang memiliki nilai Loan to Deposit Ratio berada di kisaran nilai ketentuan yang telah ditetapkan Bank Indonesia yaitu 72\%-98\% disarankan agar tetap mempertahankan keseimbangan antara penyaluran kredit dengan penghimpunan dana agar bank dapat dinilai tetap likuid dan menjalankan fungsi intermediasinya dengan baik. Bank diharapkan agar lebih maksimal dalam mengawasi penyaluran kredit dengan memilih dan memilah nasabah yang akan diberikan kredit agar penghimpunan dana dari nasabah ataupun pihak ketiga tidak akan terjadi kesulitan. (4) Bagi bank yang memiliki nilai Return On Asset di atas nilai ketentuan yang telah ditetapkan Bank Indonesia yaitu minimal $1,5 \%$ disarankan agar tetap mempertahankan kemampuan dalam menghasilkan laba dengan 


\section{JURNAL PENDIDIKAN AKUNTANSI DAN KEUANGAN}

Vol. 5, No. 1, [Januari-Juni], 2017 : 39-54

memaksimalkan aktiva yang dimiliki. Sehingga investor akan tertarik kepada bank yang memperoleh laba tinggi. Bagi bank yang masih memiliki return on asset di bawah $1,5 \%$ disarankan untuk meningkatkan kemampuan dalam meningkatkan laba. Bank dapat meningkatkan laba dengan memaksimalkan aktiva yang dimiliki, sehingga dengan total aktiva yang tetap bank dapat meningkatkan laba bersih. Apabila laba bersih meningkat maka rasio ROA pun akan terus meningkat. (5) Bank diharapkan dapat meningkatkan harga saham agar dapat meningkatkan kelangsungan usahanya. Bank dapat meningkatkan harga saham dengan cara menjaga rasio-rasio keuangan agar tetap berada pada standar penilaian tingkat kesehatan bank yang telah ditentukan Bank Indonesia. Bank disarankan untuk selalu memperhatikan faktor-faktor yang dapat mempengaruhi perubahan harga saham tersebut diantaranya adalah permodalan bank, risiko kredit bank, risiko likuiditas bank, dan rentabilitas bank. Dengan menjaga rasio-rasio keuangan maka kinerja bank akan selalu berada pada kondisi yang baik. (6) Bagi peneliti selanjutnya yang tertarik untuk meneliti pengaruh kinerja keuangan terhadap harga saham bank disarankan juga untuk meneliti sektor lain dengan menggunakan populasi dan sampel yang lebih besar serta menambahkan faktorfaktor lainnya yang mempengaruhi harga saham bank seperti laba per lembar saham (Earning per Share), tingkat bunga, tingkat resiko dan pengembalian, leverage keuangan, leverage operasi, inflasi, dan sebagainya.

\section{Daftar Pustaka}

Ang, Robert. (2007). Buku Pintar Pasar Modal Indonesia (The Intelligent Guide To Indonesian Capital Market). Edisi Pertama. Jakarta: Mediasoft Indonesia
Anoraga, Pandji dan Pujikarti, (2006). Pengantar Pasar Modal, Cetakan Kelima, Jakarta : PT Asdi Mahasatya

Alwi, Z. Iskandar. (2008). Pasar Modal Teori dan Aplikasi. Jakarta: Yayasan Pancur Siwah

Arifin, Ali. (2004). Membaca Saham. Yogyakarta : Andi

Arikunto, Suharsimi. (2010). Prosedur Penelitian Suatu Pendekatan Praktik. Jakarta : Rineka Cipta

Brigham dan Houston. (2010). Dasar-dasar Manajemen Keuangan. Edisi 11. Jakarta : Salemba Empat

Darmadji, Tjiptono., dan Fakhruddin, Hendy M. (2011). Pasar Modal Di Indonesia, Edisi 3. Jakarta : SalembaEmpat

Darmawi, Herman. (2011). Manajemen Perbankan. Jakarta: Bumi Aksara

Dendawijaya, Lukman. (2000). Manajemen Perbankan. Jakarta: Ghalia Indonesia

(2009). Manajemen Perbankan. Jakarta: Ghalia Indonesia

Fahmi, Irham. (2010). Analisis Laporan Keuangan. Bandung : Alfabeta

(2011). Analisis Laporan Keuangan. Bandung : Alfabeta (2012). Pengantar Pasar Modal. Bandung : Alfabeta

Fahmi, Irham., dan Hadi, Yovi Lavianti. (2009). Teori Portofolio dan Analisis Investasi. Bandung : Alfabeta

Ghozali, Imam. (2007). Aplikasi Analisis Multivariate Dengan SPSS. Cetakan Empat. Semarang : BP Universitas Diponegoro

(2013). Aplikasi Analisis Multivariate Dengan SPSS. Edisi Tujuh. Semarang : BP Universitas Diponegoro

Habib, Arief. (2008). Kiat Jitu Peramalan Saham. Jakarta : Gramedia

Hadi, Nor. (2013). Pasar Modal. Yogyakarta : Graha Ilmu

Hanafi, Mamduh M., dan Halim, Abdul. (2007). Analisis Laporan Keuangan. Yogyakarta: AMP-YKPN

Hasibuan, S.P. Malayu. (2009). Dasar-dasar Perbankan. Jakarta: Bumi Aksara 
Ismail. (2009). Manajemen Perbankan: Dari Teori Menuju Aplikasi. Jakarta: Kencana

Jogiyanto. (2008). Teori Portofolio dan Analisis Investasi. Edisi Kelima, Yogyakarta : BPFE.

Kasmir. (2008). Bank dan Lembaga Keuangan Lainnya. Edisi Revisi. Jakarta : PT RAJAGRAFINDO PERSADA . (2011). Analisis Laporan Keuangan. Jakarta: PT Raja Grafindo Persada

Kuncoro, Mudrajad., dan Suhardjono. (2011). Manajemen Perbankan Teori dan Aplikasi. Yogyakarta: BPFE Yogyakarta

Martalena dan Malinda, Maya. (2011). Pengantar Pasar Modal. Edisi Pertama. Yogyakarta : ANDI

Nazir, Moh. (2014). Metode Penelitian. Jakarta : Ghalia Indonesia

Prawirosentono, Suyadi. (2008) Kebijakan Kinerja Karyawan. Yogyakarta : BPFE

Riyadi, Slamet. (2006). Banking Assets and Liability Management. Edisi Ketiga. Jakarta: Lembaga Penerbit Fakultas Ekonomi Universitas Indonesia

Rivai, Veithzal., Basir, Sofyan., Sudarto, Sarwono., dan Veithzal, Arifiandy Permanata. (2013). Commercial Bank Mnagement: Manajemen Perbankan Dari Teori Ke Praktik. Edisi 1. Jakarta: (2013). Ekonometrika Teori dan Aplikasi dengan Eviews. Bandung :Labolatorium Pendidikan Ekonomi dan Koperasi

Rusdin. (2006). Pasar Modal: Teori, Masalah dan Kebijakan Dalam Praktik. Bandung : Alfabeta . (2008). Pasar Modal: Teori, Masalah dan Kebijakan Dalam Praktik. Bandung : Alfabeta

Sartono, Agus. (2010). Manajemen Keuangan Teori dan Aplikasi. Edisi Keempat. Yogyakarta :BPFE

Sudirman, I. Wayan. (2013). Manajemen Perbankan. Edisi Kedua. Jakarta: Kencana

Sudjana. (2003). Teknik Analisis Regresi dan Korelasi. Bandung : Tarsito
Sugiyono. (2008). Metode Penelitian Bisnis. Bandung : Alfabeta (2010). Statistika Untuk Penelitian. Bandung :Alfabeta (2012). Metode Penelitian Kuantitatif, Kualitatif dan R\&D. Bandung : Alfabeta (2013). Statistika Untuk Penelitian. Bandung :Alfabeta

Susilo, Bambang. (2009). Psar Modal : Mekanisme Perdagangan Saham, Analisis Sekuritas, dan Strategi Investasi di Bursa Efek Indonesia (BEI). Yogyakarta: UPP STIM YKPN

Sutrisno, Edi. (2005). Manajemen Keuangan Teori Konsep dan Aplikasi. Yogyakarta : Ekonosia . (2009). Manajemen Keuangan Teori, Konsep dan Aplikasi. Yogyakarta : Ekonosia

Umar, Husein. (2008). Metode Penelitian Untuk Skripsi dan Tesis Bisnis. Jakarta : PT Grafindo Persada

Sumber Jurnal :

Haryetti. (2012). Analisis Pengaruh Kinerja Keuangan Terhadap Harga Saham Pada Perusahaan Perbankan yang Go Public Di Bursa Efek Indonesia. Jurnal Sosial Ekonomi Pembangunan Tahun III No. 7

Hashem, Firas Na'el Rawhi. (2017). The Impacts of Non-Performing Loans Upon The Price of Stock in Jordanian Commercial Banks. Ccounting and Finance Research Vol. 6 No. 1

Husna, Nailal. (2016). Analisis Pengaruh Kinerja Keuangan Terhadap Harga Saham Perusahaan Perbankan. e-jurnal Apresiasi Ekonomi Volume 4 Nomor 2

Idawati, Wiwi., dan Wahyudi, Aditio. (2015). Effect of Earning Per Sahres (EPS) and Return On Assets (ROA) against Share Price on Coal Mining Company Listed in Indonesia Stock Exchange. An International Peer-reviewed Journal ISSN: 2422-8397 Vol. 7 No. 5

Lestari, Saptorini Dyah. (2015). Pengaruh Capital, Earning dan Liquidity Terhadap Perubahan Harga Saham Bank. Jurnal Ilmu \& Riset Akuntanis Vol. 4 No. 9

Manajer, Placido M. (2012). Impact Of Selected Financial Variables On Share Price Of 


\section{JURNAL PENDIDIKAN AKUNTANSI DAN KEUANGAN}

Vol. 5, No. 1, [Januari-Juni], 2017 : 39-54

Publicly Listed Firms In The Philippines. American International Journal of Contemporary Research. Vol. 3 No. 9

Satria, Indra., dan Hatta, Iha Haryani. (2015). Pengaruh Kinerja Keuangan Terhadap Harga Saham 10 Bank Terkemuka Di

Indonesia. Fakultas Ekonomi dan Bisnis, Universitas Pancasila

Shah, Said., Shah, S.M. Amir., and Amjad, Shehla. (2013). The Impact of Selected Financial Ratios on Share of Companies in Pakistan: 1999-2006. Proceedings of 6th International Business and Social Sciences Research Conference

Ulfa, Maria., dan Budiyanto. (2014). Pengaruh Kinerja Keuangan Terhadap Harga Saham Bank Umum Milik Pemerintah Di BEI. Sekolah Tinggi Ilmu Ekonomi Indonesia (STIESIA) Surabaya

Wulandari, Ana. (2015). Pengaruh Kinerja Keuangan Perbankan Terhadap Harga Saham yang Ditawarkan Di Bursa Efek Indonesia (Studi Kasus 10 Bank Dengan Aset Terbesar). Jurnal Riset Mahasiswa Manajemen. ISSN: 2337-5655. Volume: 3, Nomor: 1 